\title{
Morphological Characterization of Diaphragm in Common Squirrel Monkey (Saimiri sciureus)
}

\author{
JOSÉ RICARDO N. DE SOUZA NETO ${ }^{1}$, ÉRIKA BRANCO ${ }^{1}$, ELANE G. GIESE ${ }^{2}$ and ANA RITA DE LIMA ${ }^{2}$ \\ ${ }^{1}$ Laboratório de Pesquisa Morfológica Animal/LaPMA, Faculdade de Medicina Veterinária, Universidade Federal \\ Rural da Amazônia/UFRA, Avenida Presidente Tancredo Neves, 2501, Montese, 66077-530 Belém, PA, Brazil \\ ${ }^{2}$ Laboratório de Histologia e Embriologia Animal/LHEA, Faculdade de Medicina Veterinária, Universidade Federal \\ Rural da Amazônia/UFRA, Avenida Presidente Tancredo Neves, 2501, Montese, 66077-530 Belém, PA, Brazil
}

Manuscript received on March 8, 2017; accepted for publication on September 11, 2017

\begin{abstract}
The wall of the diaphragm can be affected by congenital or acquired alterations which allow the passage of viscera between the abdominal and chest cavities, allowing the formation of a diaphragmatic hernia. We characterized morphology and performed biometrics of the diaphragm in the common squirrel monkey Saimiri sciureus. After fixation, muscle fragments were collected and processed for optical microscopy. In this species the diaphragm muscle is attached to the lung by phrenopericardial ligament. It is also connected to the liver via the coronary and falciform ligaments. The muscle is composed of three segments in total: 1) sternal; 2) costal, and 3) a segment consisting of right and left diaphragmatic pillars. The anatomical structures analyzed were similar to those reported for other mammals. Histological analysis revealed stable, organized muscle fibers with alternation of light and dark streaks, indicating transverse striation.
\end{abstract}

Key words: diaphragmatic hernia, morphology, Saimiri sciureus.

\section{INTRODUCTION}

Knowledge of surface anatomy is essential for understanding basic topographical anatomy, and is needed for various tasks such as patient examination, interpretation of diagnostic images, and performance of surgery or other medical procedures (Sayeed and Darling 2007, Elliott et al. 2010).

The respiratory system is complex because continuous respiratory muscle contraction is requires for lung ventilation. It is usually under automatic

Correspondence to: Ana Rita de Lima

E-mail: vetlima@uol.com.br control of respiratory centers in the medullary region of the brainstem, and in mammals, inspiration is the crucial phase of the respiratory cycle (Feldman and Del Negro 2006, Feldman 2011). The muscles involved in respiratory process are the diaphragm, scalenes, and intercostals (Druz and Sharp 1981). Among these, the diaphragm is the most important, contributing between $60 \%$ and $80 \%$ of the body's respiratory force (Wilson and Hayes 1986, Supinski et al. 1996, Shindoh et al. 2009).

Morphological studies of the diaphragm are important because irregularities may cause diaphragmatic hernias, which are classified in 
two major categories: congenital and acquired. Congenital diaphragmatic hernia $(\mathrm{CDH})$ is a partial protrusion of abdominal organs through a defect in the diaphragm. $\mathrm{CDH}$ is caused by a failure in the fusion of the pleuroperitoneal folds that manifests as a defect during fetal development (Friedenwald and Feldman 1925, Adeleman and Benson 1976, Gerszten et al. 1976, Munizaga et al. 1978). Three types of CDH have been described in humans: Bochdalek-type $\mathrm{CDH}$, which presents as a protrusion through the posterolateral part of the diaphragm (Haller 1986, Salaçin et al. 1994, Colvin et al. 2005, Gaxiola et al. 2009); Morgagni CDH, an exremely rare pathology caused by defects in the development of the sternal fixation (Rodríguez Hermosa et al. 2003); and hiatal hernia, which is caused by trauma (Skandalakis 2004, Bastos et al. 2008).

The diaphragm surface is concave facing the thoracic cavity and convex facing the abdominal cavity, resulting in a dome-like shape. It is covered by the peritoneum on the abdominal face and serves as a border between the thoracic and abdominal cavities (Getty 1986, Dyce et al. 2010). In humans, the diaphragm muscle is directly associated with hiccups, which result from diaphragmatic spasm at the moment of inspiration concomitant with the closure of the glottis. There are many causes, and in severe cases hiccups are linked to diaphragmatic hernias and gastrointestinal causes, such as the hiatal hernia and gastroesophageal reflux (Cardoso and Xavier 2011).

Saimiri sciureus, known as a common squirrel monkey, inhabits tropical dry and temporarily flooded forests. This species is diurnal and characterized by having short and thick greenishyellow fur. They have rounded heads and markings on the back, a black snout, rounded ears, well developed fingers, and a non-prehensile tail; they are omnivorous, feeding on flowers, insects and small vertebrates (Auricchio 1995).
Non-human primates are among the most studies groups of mammals in the wild and in captivity (Cubas et al. 2007); however, data on the morphology of many species is scarce. This study investigates morphological features of the squirrel monkey respiratory system from a functional point of view, including location and histology of the diaphragm. We hope to generate further discussion on which to base future research with other species.

\section{MATERIALS AND METHODS}

Six, male Saimiri sciureus specimens were evaluated in the study, including 5 adults and 1 juvenile. Specimens died of natural causes and were donated by the National Primate Center (CENP) in Ananindeua, Pará, Brasil. The study took place at the Research Laboratory of Animal Morphology (LaPMA) at the Federal Rural University of Amazonia with approval by the Committee for Research with Animals (CEPAN /IEC/SVS/MS $\mathrm{N}^{\circ}$ 008/2010).

Specimens were fixed in $10 \%$ aqueous formaldehyde solution. After fixation, an incision was made along the ventral midline and skin and subcutaneous tissue of the sternal manubrium was folded to the umbilical scar, allowing visualization of the abdominal cavity. All organs were removed to expose the caudal face of the diaphragm muscle. Photos were taken and morphometric data was collected using a caliper. We measured the length and width of the muscle from equally spaced points. Nomenclature for structures was in accordance with the Anatomical Veterinary Nomenclature (International Committee on Veterinary Gross Anatomical Nomenclature 2012).

Samples of diaphragm muscle tissue were fixed with 4\% formaldehyde. Following overnight fixation, the tissues were embedded in paraffin, sectioned to $5 \mu \mathrm{m}$ thickness in a Zeiss Hyrax M25 microtome, and stained with hematoxylin and eosin and Gomori trichrome to observe the collagen 


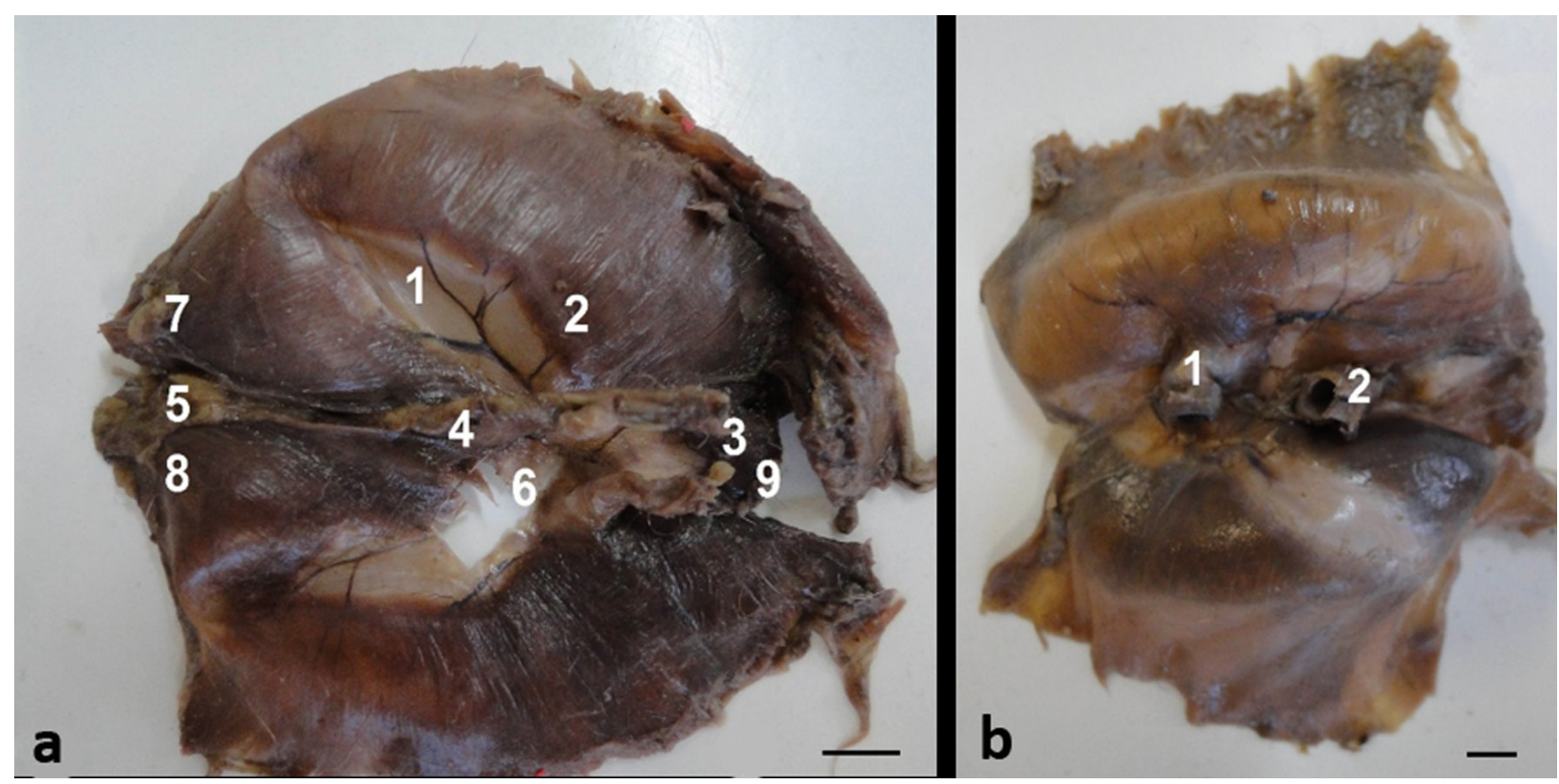

Figure 1 - Fotomacrography of abdominal face of the diaphragm of the Saimiri sciureus. a - tendinous center (1), part of the costal diaphragm dome (2), sternal part of the diaphragm dome (3), esophageal hiatus (4), aortic hiatus (5), foramen of the caudal vena cava (6), diaphragmatic pillars right (7), diaphragmatic pillars left (8) and xiphoidal process (9). b - Esophagus (1) and phrenicopericardic ligament (2). Scale bar: $1 \mathrm{~cm}$.

fibers. Images were taken using a Leica DM 2500 microscope with camera attachment (Leica DFC 310FX).

\section{RESULTS}

The diaphragm muscle of $S$. sciureus is domeshaped, convex facing the abdomen and concave facing the chest. It is connected to the lung by the phrenicopericardial ligament, located caudally from the lungs and heart. The diaphragm is connected to the liver by the coronary and the falciform ligaments.

The central region of the diaphragm is composed of fibrous connective tissue called the central tendon, which contains and aperture called the vena cava foramen which transmits the inferior vena cava. This is a region anatomically fragile of diaphragm. The peripheral region is formed by a muscle portion which contained two apertures. The first aperture is the esophageal hiatus, through which the abdominal region of the esophagus
TABLE I

Biometric values of diaphragm muscle in Saimiri sciureus.

\begin{tabular}{ccc}
\hline Animal & Length & Width \\
\hline M1 & $64.6 \mathrm{~mm}$ & $63.0 \mathrm{~mm}$ \\
M2 & $68.5 \mathrm{~mm}$ & $58.1 \mathrm{~mm}$ \\
M3 & $54.3 \mathrm{~mm}$ & $51.0 \mathrm{~mm}$ \\
M4 & $61.5 \mathrm{~mm}$ & $74.6 \mathrm{~mm}$ \\
M5 & $63.3 \mathrm{~mm}$ & $69.7 \mathrm{~mm}$ \\
M6 & $67.0 \mathrm{~mm}$ & $81.0 \mathrm{~mm}$ \\
Average & $63.2 \mathrm{~mm}$ & $66.2 \mathrm{~mm}$ \\
Standard deviation & $14.3 \mathrm{~mm}$ & $30.2 \mathrm{~mm}$ \\
\hline
\end{tabular}

passes, and the second is the aortic hiatus, through which the aorta, azygous vein and thoracic duct pass (Fig. 1a and b).

The muscle is subdivided into three regions. The sternal region is fixed cranially to the xiphoidal process of the sternum. The coastal region has bars of cartilage that connect to the ribs called costal cartilages. The third regions are formed by the right and left diaphragmatic pillars, which lie opposite 
the central tendon. The insertion of the diaphragm is at the level of the eighth rib.

The average length of the diaphragm along the dorsoventral axis was $63.2 \pm 14.3 \mathrm{~mm}$ (mean \pm S.D.), and average width along the latero-lateral axis was $66.26 \pm 30.2 \mathrm{~mm}$ (Table I). Optical microscopy showed that skeletal muscle fiber of the diaphragm contained transverse striations, visualized by alternating patterns of light and dark streaks (Fig. 2). Nuclear lysis prevented visualization of the nucleus. The epimysium and endomysium were present, which are sheaths of fibrous tissue enveloping the muscle. The endomysium is formed by basal lamina of the muscle fiber in association with reticular fibers.

\section{DISCUSSION}

The zoology, comparative and experimental anatomy, physiology, medicine, physics, and philosophy are areas that has been studied the diaphragm muscle for a long time. The diaphragm as a unique and vital respiratory muscle (Lessa et al. 2016).
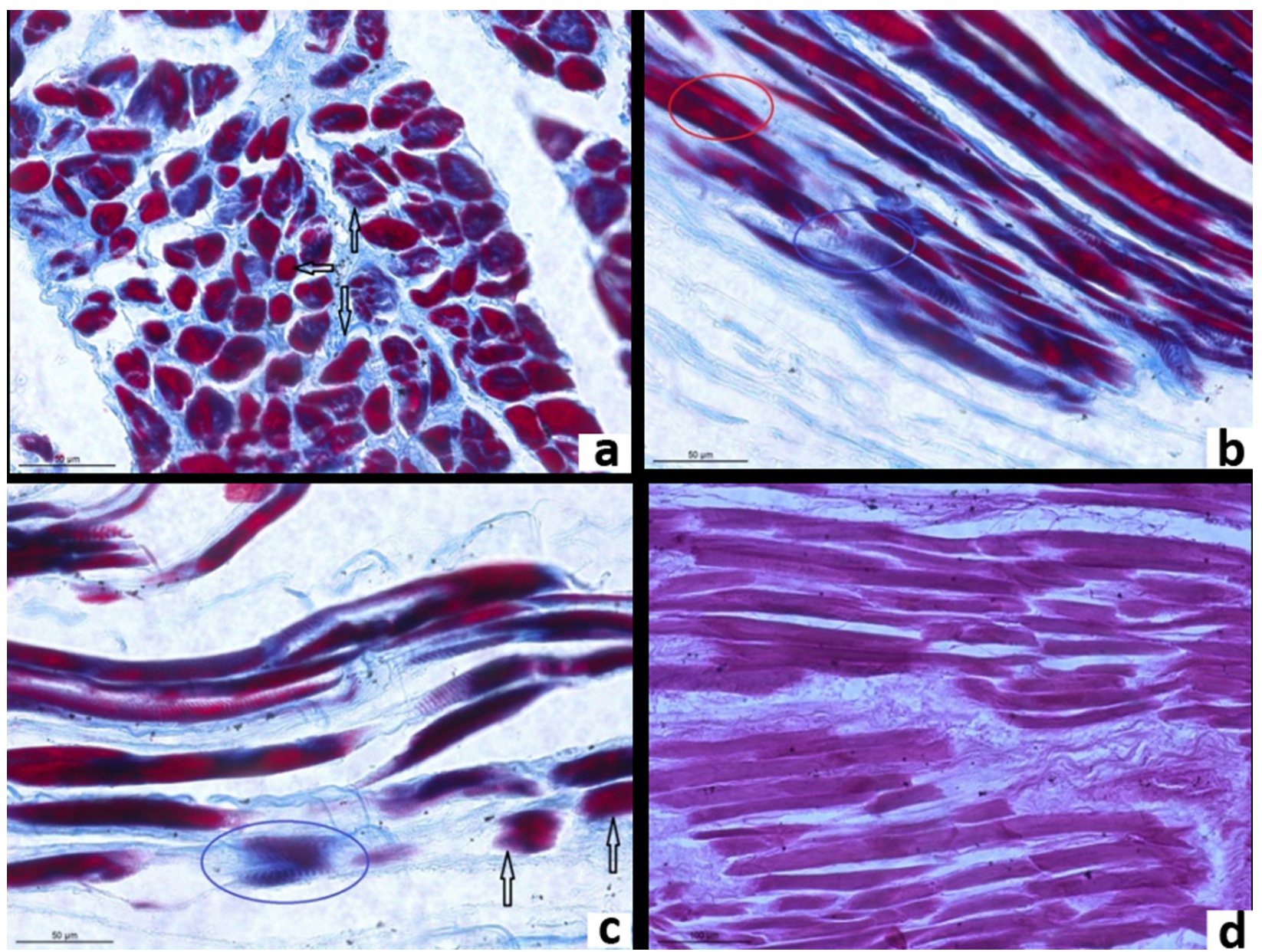

Figure 2 - Photomicrographs of sectional portion of diaphragmatic muscle. a - show the diameter of the muscle fibers staple in varying sizes (arrows). Stained: Masson trichrome. Scale Bar: $50 \mu \mathrm{m}$. b - oblique cut the muscle portion with subsequent staining using Gomori trichrome revealed the diaphragmatic muscles (red circle) and the collagen fibers (blue circle). It was observed that the variety in the diameter of muscle fibers and staple their striae. Scale Bar: $50 \mu \mathrm{m}$. c-provision of muscle fibers (arrows) and mainly of striae. Stained: Masson trichrome. Scale Bar: $50 \mu \mathrm{m}$. d - muscle fibers and striae. Stained: Hematoxylin-eosin. Scale Bar: $100 \mu \mathrm{m}$. 
Shen et al. (2016), in a study with a human Chinese population indicated that that the inferior vena cava (IVC), esophagus and aorta most commonly pass through the diaphragm at vertebral levels T10, T11 and T12, respectively. This is markedly different from more dated descriptions by Moore et al. (2010) and Sinnatamby (2011), who indicated T8 and T10, respectively. The rule of " 8 , 10,12 " thus might more accurately be replaced by "10, 11, 12". In Saimiri sciureus the caudal vena cava, esophagus, and aorta pass through the diaphragm at the level of T8, an organization which is similar to that of humans.

Hernias are pathologies that can affect the diaphragm, and can be classified under two major categories: congenital and acquired. Acquired diaphragmatic hernias are traumatic in nature (Skandalakis 2004). The CDH described in humans are Bochdalek, Morgagni and hiatal hernia. The Bochdalek CDH occurs more frequently on the left side of the diaphragm (Colvin et al. 2005, Moore et al. 2010, Bianchi et al. 2013). Bochdalek CDH occurs in $1 / 3,600$ infants or $1 / 7,000$ neonates, and can potentially develop into life-threatening cardiopulmonary complications (Fine et al. 1987, Berman et al. 1988, Thomas and Kaput 1991, Salaçin et al. 1994, Wilson et al. 2001). By contrast, in adults, Bochdalek CDH is symptomatic, and was historically difficult to diagnose until the advent of effective radiological diagnostics (Bockus 1963, Chui and Tan 1993, Alam and Chander 2005, Kumar et al. 2009, Venkatesh et al. 2011).

Morgagni CDH is a rare disease caused by the defective development of the sternal attachments of the diaphragm. It is found more commonly on the right side of the midline than on the left side, as the left side is protected by the pericardium (Rodríguez et al. 2003). Bilateral defects have also been described (Allocca et al. 2000, Al-Salem 2007). Morgagni hernia accounts for $2-5 \%$ of all congenital diaphragmatic defects (Rodríguez et al. 2003, Al-Salem 2007). The condition is usually discovered in older children or adults as an incidental finding during chest radiography, or after becoming symptomatic due to recurrent chest infections (Al-Salem 2007), visceral obstruction (Rodríguez et al. 2003), or breathing restriction (Matsushita et al. 2007, Lammy et al. 2013). These diaphragmatic defects have a high incidence of associated congenital anomalies, including neural tube defects, congenital heart defects, intestinal rotation anomalies, pectus excavatum, and chromosomal abnormalities such as trisomies 3, 18, and 21 (Schumpelick et al. 2000).

Morgagni hernia in animals has only been described for three horses (Pauwels et al. 2007) and two bitches (Gradela et al. 2013). Bochdalek hernia has not been reported in animals. In humans, the estimated incidence of CDH is 1 in 2,000-5,000 live births. $\mathrm{CDH}$ is a serious birth defect characterized by incomplete formation of the diaphragm, resulting in herniation of the abdominal viscera that extends into the thoracic cavity (Doyle and Lally 2004, Pober 2007). The etiology of congenital diaphragmatic hernia is unknown, however, $2 \%$ of cases were familial and another $15 \%$ of patients have associated chromosomal abnormalities (King and Booker 2005).

$\mathrm{CDH}$ can occur as an isolated or complex defect associated with other congenital anomalies, most commonly heart, brain, renal and genitourinary malformations (Pober 2007). Pulmonary hypoplasia is an important defect in congenital diaphragmatic hernia (King and Booker 2005), and the severity of this pathology is largely dependent on the degree of pulmonary hypoplasia, pulmonary hypertension, and associated malformations.

In laboratory rats, pericardial diaphragmatic hernia has been associated with Vitamin A deficiency (Waldron and Leib 1993). Prenatal exposure to 2,4-dichloro-phenyl-p-nitrophenyl ether (a toxic herbicide also known as nitrofen) can cause a dorsolateral type of hernia (Kluth et al. 1990). 
Congenital pleuroperitoneal hernias are rare in canines, and usually take the form of a defect in the dorsolateral diaphragm with or without central tendon involvement (Venkatesh et al. 2011). Congenital pleuroperitoneal hernias have also been diagnosed in cats (Voges et al. 1997). Congenital pleuroperitoneal hernias are rarely diagnosed in small animals, because many affected animals die at birth or soon after (Fossum 2007).

Peritoneopericardial hernias commonly affect the omentum, liver lobes, gallbladder, and small intestine due to direct communication between the peritoneal and pericardial cavities. The stomach, colon, falciform ligament, and spleen can also be affected. Cystic lesions in the pericardium have been reported in animals with small peritoneopericardial hernias and pathological changes of the omentum or liver (Liptak et al. 2002). Mortality may occur in up to $14 \%$ of dogs and cats undergoing surgery for peritoneopericardial hernia (Evans and Biery 1980, Reimer et al. 2004).

In wild animals, one case of hiatal hernia was described in a female northern elephant seal (Mirounga angustirostris). This pathology causes passage of part the stomach to the thoracic cavities, which in this case was solved by laparoscopic gastropexy (Greene et al. 2015).

Hiatal hernia is uncommon in dogs and rare in cats (Hunt and Johnson 2003). It is the displacement of any abdominal structure through the esophageal hiatus toward the caudal mediastinum; usually the herniation occurs in the abdominal esophagus or gastroesophageal junction, and sometimes a portion of the cardic and/or fundus region (Miles et al. 1988, Wallace et al. 1992, Fossum 2007).

Injuries may also cause problems with the diaphragm, and trauma may traverse the diaphragm to affect abdominal contents. Right-sided diaphragmatic injuries are generally prevented due to protection by the liver, and present less risk for herniation or injury to the gastrointestinal tract (Bastos et al. 2008). Diaphragm hernia caused by trauma is more common on the right side, where a portion of omentum, colon, or stomach may herniate into the thoracic cavity (Skandalakis 2004). Herniation of abdominal organs into the thoracic cavity may result in the inability of the lung to inflate, and reduced functional residual capacity (FRC) (Wilson et al. 1971).

In domestic and wild animals, traumatic diaphragmatic hernia most often develops as a result of blunt abdominal trauma (particularly motor vehicle accidents), resulting in sudden increase in abdominal pressure and subsequent disruption of the diaphragm (Thomas and Kaput 1991, Schmiedt et al. 2003, Fossum 2007) in anatomical fragile points. Surgical repair of traumatic diaphragmatic hernia is necessary to replace abdominal contents, relieve respiratory compromise, and re-establish diaphragmatic function. Up to $85 \%$ of diaphragmatic hernias in small animals are traumatic in origin, $5-10 \%$ are congenital, and the rest are of unknown etiology (Warkany and Roth 1948, Wilson and Hayes 1986, Boudrieau 1993).

The diaphragm muscle of Saimiri sciureus is a musculotendinous partition that separates the thoracic and abdominal cavities. Development of this organ during gestation is rapid, as it is essential for the respiratory function and survival of the animal. The central tendon is the region where phrenic nerves control contractile process of muscles (Wynn et al. 2013). In carnivores, the phrenic nerves branch off the diaphragm muscle and are the only source of motor innervation. Carnivore phrenic nerve sensory fibers are supplemented by branches issued by intercostal nerves, as was observed in S. sciureus.

The abdominal wall of Saimiri sciureus grants stability for effective contraction of the diaphragm, as observed in humans. The muscle promotes sustenance for the viscera during inspiration, and depends on the stability of paravertebral lumbar muscles which lead to vertebral insertion of the diaphragm. These muscles prevent elevation 
of the rib cage, characterizing a synergistically antagonistic relationship (Bennati 2001). As found in this study, the diaphragm muscle fiber architecture in mammals is discontinuous in nature, an important characteristic for synchronized muscle contraction (Lessa et al. 2012).

In the present work, the diaphragm muscle was divided into three parts: lumbar, sternum and costal, as also found in domestic carnivores by other authors Getty 1986, Popesko 1990, Evans and Lahunta 1994, Sayeed and Darling 2007, Dyce et al. 2010, Moore et al. 2010). The muscle possessed a central tendon through which the caudal vena cava, aorta, thoracic duct, esophagus, and azygous vein passed.

In the common squirrel monkey, the central tendon is "V-shaped" and located in the transverse plane, as found in the majority of mammals (Getty 1986, Dyce et al. 2010, Lessa et al. 2014). The Guinea pig show a tendinous center "U-shaped" (Lessa et al. 2013). On exception is manatees (Trichechus manatus latirostris), in which the diaphragm is "I-shaped" and presents fibers in the central tendon that are attached to bone epiphysis and persist until the vertebral bodies, producing two hemi-diaphragms (Rommel and Reynolds 2000). In another study with Oryctolagus cuniculus, the muscular portion of the diaphragm was composed of eight muscle fascicles, symmetrical in each antimere of animal (Pompeu 1992).

There is a thin layer of tissue called endomysium outside of the sarcolemma around the fibers in Saimiri sciureus; each fiber is surrounded by connective tissue forming the perimysium. The outermost layer surrounding the diaphragm muscle is called epimysium (Getty 1986, Junqueira and Carneiro 2004). The central center of the common squirrel monkey has Type I and II of collagen fibers. In goats, $58.9 \%$ of fibers present are Type I, and $41.1 \%$ are Type II. In humans, more than 50\% of these fibers are Type I (Ibebunjo 1993).

\section{CONCLUSIONS}

The diaphragm of the Saimiri sciureus contained three apertures in the muscle (vena cava foramen, aortic hiatus, and esophageal hiatus). This result is in agreement with descriptions of other mammals. The central tendon is V-shaped, similar to the shape in the albino rat and crab-eating raccoon. This region is fragile and in case of traumas can be suffer lesion/hernia diaphragmatic. The muscle fibers are stable and organized, with alternating light and dark streaks indicating transverse striation.

Anatomical studies of the diaphragm in different species is crucial for our knowledge of hernia occurrence in animals, and is relevant for human health due to similarities in pathology.

Acquired diaphragmatic hernias are caused by trauma, in particular trampling, and require surgical correction. Delays in seeking care for affected animals can diminish the probability of survival. We did not encounter reports of congenital or acquired hernias in wild animals, with the exception of one case of hiatal hernia in a northern elephant seal.

Biometric values of diaphragm muscle in Saimiri sciureus were not comparable to any data in the literature, however, considering the values we suggest that the best type of suture is nonabsorbable sutures, and monoetilamine, nylon, or polypropylene 4-0 or 5-0 are strongly indicated.

\section{REFERENCES}

ADELEMAN S AND BENSON CD. 1976. Bochdalek hernias in infants: Factors determining mortality. J Pediatr Surg 11: 569-573.

ALAM WCA AND CHANDER BN. 2005. Adult Bochdalek hernia. Armed Forces Med J India 61: 284-286.

AL-SALEM AH. 2007. Congenital hernia of Morgagni in infants and children. J Pediatr Surg 42: 1539-1543.

ALLOCCA A, STECCO A, SALTI S, CAPACCIOLI L AND PERNICE LM. 2000. Bilateral Morgagni-Larrey hernia Report of a clinical case. Minerva Chir 55: 273-278.

AURICCHIO P. 1995. Primatas do Brasil. Terra Brasilis: Guarulhos, 168 p. 
BASTOS R, BAISDEN CE, HARKER L AND CALHOON JH. 2008. Penetrating Thoracic Trauma Semin Thorac Cardiovasc Surg 20: 19-25.

BENATTI AT. 2001. Equilíbrio tóraco-abdominal integrada à respiração e à postura. Arq Ciên Saúde 5: 87-92.

BERMAN L, STRINGER D, EIN SH AND SHANDLING B. 1988. The late-presenting pediatric Bochdalek hernia: a 20-year review. J Pediatr Surg 23: 735-739.

BIANCHI E, MANCINI P, VITO SD, POMPILI E, TAURONE S, GUERRISI I, GUERRISI A, D'ANDREA V, CANTISANI V AND ARTICO M. 2013. Congenital asymptomatic diaphragmatic hernias in adults: a case series. J Med Case Rep 7: 125.

BOCKUS HL. 1963. Gastroenterology. Saunders, Philadelphia, $333 \mathrm{p}$.

BOUDRIEAU R. 1993. Pathophysiology of traumatic diaphragmatic hernia. In: Bojrab MJ (Ed), Mechanisms of Disease, Lea \& Febiger, Philadelphia, p. 103.

CARDOSO MCAF AND XAVIER ACF. 2011. Soluço: características e possibilidades fonoterapêuticas. Arquivos Int Otorrinolaringol 15: 89-95.

CHUI P AND TAN C. 1993. Sudden death due to incarcerated Bochdalek hernia in an adult. Ann Acad Med Singapore 22: 57-60.

COLVIN J, BOWER C, DICKINSON JE AND SOKOL J. 2005. Outcomes of Diaphragmatic Hernia: A population Based Study in Western Australia. Pediatrics 116: e356-e363.

CUBAS ZS, SILVA JCR AND CATÃO-DIAS JL. 2007. Tratado de Animais Selvagens. Roca, São Paulo, 2470 p.

DOYLE NM AND LALLY KP. 2004. The CDH Study Group and advances in the clinical care of the patient with congenital diaphragmatic hernia. Semin Perinatol 28: 174-184.

DRUZ WS AND SHARP JT. 1981. Activity of respiratory muscles in upright and recumbent humans. J Appl Physiol 51: 1552-1561.

DYCE KM, SACK WO AND WESING CJG. 2010. Tratado de anatomia veterinária, $2^{\mathrm{a}}$ ed., Guanabara Koogan, Rio de Janeiro, $856 \mathrm{p}$.

ELLIOTT DS, BAKER PA, SCOTT MR, BIRCH CW AND THOMPSON JM. 2010. Accuracy of surface landmark identification for cannula cricothyroidotomy. Anaesthesia 65: 889-894.

EVANS HE AND LAHUNTA A. 1994. Guia para a dissecção do cão, $3^{\mathrm{a}}$ ed., Guanabara Koogan, Rio de Janeiro.

EVANS S AND BIERY DN. 1980. Congenital peritoneopericardial diaphragmatic hernia in the dog and cat: A literature review and 17 additional case histories. Vet Radiol Ultrasound 21: 108-116.

FELDMAN JL. 2011. Chapter 14 - looking forward to breathing. Prog Brain Res 188: 213-218.

FELDMAN JL AND DEL NEGRO CA. 2006. Looking for inspiration: new perspectives on respiratory rhythm. Nat Rev Neurosci 7: 232-242.
FINE R, BORRERO E AND STONE A. 1987. Bochdalek Hernia in Adulthood. New York State J Med 87: 516-518.

FOSSUM TW. 2007. Surgery of the lower respiratory system: pleural cavity and diaphragm. In: Fossum TW (Ed), Small animal surgery. St. Louis: Elsevier, p. 896-929.

FRIEDENWALD J AND FELDMAN M. 1925. Report of an interesting type of diaphragmatic hernia of the cardia of the stomach through the esophageal orifice. Am J Med Sci 170: 263.

GAXIOLA A, VARON J AND VALLADOLID G. 2009. Congenital diaphragmatic hernia: an overview of the etiology and current management. Acta Paediatr 98: 621-627.

GERSZTEN E, MUNIZAGA J, ALLISON MJ AND KLURFELD DM. 1976. Diaphragmatic hernia of the stomach in a Peruvian mummy. Bull N Y Acad Med 52: 601-604.

GETTY R. 1986. Anatomia dos Animais Domésticos, 5ª ed., Guanabara Koogan, Rio de Janeiro, 787 p.

GRADELA A, MACEDO AGC, MATOS MHT, LIMA RS AND FRANZO VS. 2013. Defeitos congênitos raros associados à hérnia de Morgagni e à aplasia segmentar de corno uterino em cadela: Relato de caso. Semin Cienc Agrar 34: 1841-1850.

GREENE R, VAN BONN WG, DENNISON SE, GREIG DJ AND GULLAND FMD. 2015. Laparoscopic gastropexy for correction of a hiatal hernia in a northern elephant seal (Mirounga Angustirostris). J Zoo Wildl Med 46: 414-416.

HALLER SA. 1986. Professor Bochdalek and His Hernia: Then and Now. Prog Pediatr Surg 20: 252-255.

HUNT GB AND JOHNSON KA. 2003. Diaphragmatic, pericardial, and hiatal hernia. In: Slatter D (Ed), Textbook of Small Animal Surgery. Vol. 1. Elsevier Science. Philadelphia, p. 471-487.

IBEBUNJO C. 1993. Type, diameter and distribuition of fibres in some respiratory and abdominal muscles of the goat. Vet Res Commun. 17: 171-182.

INTERNATIONAL COMMITTEE ON VETERINARY GROSS ANATOMICAL NOMENCLATURE. 2012. Nomina anatômica veterinária, $5^{\text {th }} \mathrm{ed}$., Knoxville, 177 p.

JUNQUEIRA LC AND CARNEIRO J. 2004. Tecido muscular. In: Junqueira LC and Carneiro J (Eds), Histologia Básica, $10^{\mathrm{a}}$ ed., Rio de Janeiro: Guanabara Koogan, p. 184-205.

KING H AND BOOKER PD. 2005. Congenital diaphragmatic hernia in the neonate. Continuing Education in Anaesthesia. Crit Care Pain 5: 171-174.

KLUTH D, KANGAH R, REICH P, TENBRINCK R, TIBBOEL D AND LAMBRECHT W. 1990. Nitrofeninduced diaphragmatic hernias in rats: an animal model. J Pediatr Surg 25: 850-854.

KUMAR A, MAHESHWARI V, RAMAKRISHNAN TS AND SAHU S. 2009. Caecal perforation with faecal peritonitis - unusual presentation of Bochdalek hernia in an adult: a case report and review of literature. World J Emerg Surg 4: $1-6$. 
LAMMY S, STEWART M, CARNOCHAN FM AND WALKER WS. 2013. Bilateral Morgagni hernia: operative discovery of appendix lying on superior pulmonary vein. Scott Med J 58: e1-3.

LESSATB, DAFONSECAET, DEABREU DK, RODRIGUES MN, BERTASSOLI BM, SILVA FMO AND AMBRÓSIO CE. 2013. Diaphragm Morphology of Guinea Pig (Cavia porcellus). Micr Res Tec 76: 316-320.

LESSA TB, DE ABREU DK, BERTASSOLI BM AND AMBRÓSIO CE. 2016. Diaphragm: A vital respiratory muscle in mammals. Ann Anat 205: 122-127.

LESSA TB, DE ABREU DK, RODRIGUES MN, BRÓLIO MP, MIGLINO MA AND AMBRÓSIO CE. 2014. Morphological and Ultrastructural Evaluation of the Golden Retriever Muscular Dystrophy Trachea, Lungs, and Diaphragm Muscle. Micr Res Tech 77: 857-861.

LESSA TB, SILVA LCS, CONSTANTINO MVP, SANTOS PRS, ASSIS-NETO AC, BOMBONATO PP AND AMBRÓSIO CE. 2012. Morfologia comparativa do diafragma do sagui-de-tufo-branco e do sagui-de-carabranca. Biotemas 25: 119-124.

LIPTAK J, BISSETT SA AND ALLAN GS. 2002. Hepatic cysts incarcerated in a peritoneopericardial diaphragmatic hernia. J Feline Med Surg 4: 123-125.

MATSUSHITA T, SEAH P AND GANI J. 2007. Giant Morgagni hernia causing cardiac tamponade. Heart Lung Circ 16: 392-393.

MILES KG, POPE ER AND JERGENS AE. 1988. Paraesophageal hiatal hernia and pyloric obstruction in a dog. J Am Vet Med Assoc 193: 1437-1439.

MOORE KL AND DALLEY AF. 2007. Anatomia orientada para a clínica. Rio de Janeiro: Guanabara Koogan, p. 300305.

MOORE KL, DALLEY AF AND AGUR AMR. 2010. Clinically Oriented Anatomy, 6th ed., Philadelphia: Lippincott Williams \& Wilkins, 1168 p.

MUNIZAGA J, ALLISON MJ AND ASPILLAGA E. 1978. Diaphragmatic hernia associated with strangulation of the small bowel in an Atacamena mummy. Am J Phys Anthropol 48: 17-19.

PAUWELS FF, HAWKINS JF, MACHARG MA, ROTHENBUHLER RD, BAIRD DK AND MOULTON JS, 2007. Congenital retrosternal (Morgagni) diaphragmatic hernias in three horses. J Am Vet Med Assoc 231: 427-432.

POBER BR. 2007. Overview of epidemiology, genetics, birth defects, and chromosome abnormalities associated with CDH. Am J Med Genet C Semin Med Genet 145: 158-171.

POMPEU E, LIBERTI EA, OSAKA JT, RODRIGUES JR AJ AND TOLOSA EMC. 1992. The rabbit's diaphragm innervation. Rev Bras Ciênc Morf 1: 33-36.

POPESKO P. 1990. Atlas de anatomia topográfica dos animais domésticos. São Paulo: Manole, 608 p.

REIMER SB, KYLES AE, FILIPOWICZ DE AND GREGORY CR. 2004. Long-term outcome of cats treated conservatively or surgically for peritoneopericardial diaphragmatic hernia: 66 cases (1987-2002). J Am Vet Med Assoc 224: 728-732.

RODRÍGUEZ HERMOSA JI, TUCA RODRÍGUEZ F, RUIZ FELIU B, GIRONES VILA J, GARCÍA ROIG J AND CODINA CAZADOR A. 2003. Diaphragmatic hernia of Morgagni-Larrey in adults: analysis of 10 cases. J Gastroenterol Hepatol 26: 535-540.

ROMMEL S AND REYNOLDS JE. 2000. Diaphragm structure and function in the Florida Manatee (Trichechus manatus latirostris). Anat Rec 259: 41-51.

SALAÇIN S, ALPER B, CEKIN N AND GÜLMEN MK. 1994. Bochdalek hernia in adulthood: a review and an autopsy case report. J Forensic Sci 39: 1112-1116.

SAYEED RA AND DARLING GE. 2007. Surface anatomy and surface landmarks for thoracic surgery. Thorac Surg Clin 17: 449-461.

SCHMIEDT CW, TOBIAS KM AND STEVENSON M. 2003. Traumatic diaphragmatic hernia in cats: 34 cases (19912001). J Am Vet Med Assoc 222: 1237-1240.

SCHUMPELICK V, STEINAU G, SCHLUP I AND PRESCHER A. 2000. Surgical Embryology and anatomy of the diaphragm with surgical applications. Surg Clin N Am 80: 213-239.

SHEN XH, SU BY, LIU JJ, ZHANG GM, XUE HD, JIN ZY, MIRJALILI SA AND CHAO MA. 2016. A Reappraisal of Adult Thoracic and Abdominal Surface Anatomy via CT Scan in Chinese Population. Clin Anat 29: 165-174.

SHINDOH C, MURAKAMI Y, SHISHIDO R, SASAKI K, NISHIO T AND MIURA M. 2009. Tulobuterol patch maintains diaphragm muscle contractility for over twentyfour hours in a mouse model of sepsis. J Exp Med 218: 271-278.

SINNATAMBY CS. 2011. Last's Anatomy: Regional and Applied. Edinburgh: Elsevier, 560 p.

SKANDALAKIS J. 2004. Surgical Anatomy: The Embryologic and Anatomic Basis of Modern Surgery. Pas Med Public 1: 353-392.

SUPINSKI G, NETHERY D, STOFAN D AND DIMARCO A. 1996. Comparison of the effects of endotoxin on limb, respiratory, and cardiac muscles. J Appl Physiol 81: 13701378.

THOMAS S AND KAPUT B. 1991. Adult Bochdalek HerniaClinical Features, Management and Results of Treatment. Jpn J Surg 21: 114-119.

VENKATESH SP, RAVI MJ, THRISHULI PB AND SHARATH CHANDRA BJ. 2011. Asymptomatic Presentation of Bochdalek's Hernia in an Adult. Indian J Surg 73(5): 382-383.

VOGES A, BERTRAND S AND HILL RC. 1997. True diaphragmatic hernia in a cat. Vet Radiol Ultrasound 38(2): 116-119.

WALLACE J, MULLEN HS AND LESSER MB. 1992. A technique for surgical correction of peritoneal pericardial 
diaphragmatic hernia in dogs and cats. J Am Anim Hosp Assoc 28: 503.

WALDRON DR AND LEIB MS. 1993. Hiatal hernia. In: MJ Bojrab (Ed), Disease Mechanisms in Small Animal Surgery, USA: Lea \& Febiger. 1183 p.

WARKANY J AND ROTH CB. 1948. Congenital malformations induced in rats by maternal vitamin $\mathrm{A}$ deficiency. J Nutr 35: 1-4.

WILSON GP AND HAYES JR HM. 1986. Diaphragmatic hernia in the dog and cat: a 25-year overview. Semin Vet Med Surg 1: 318-326.
WILSON GP, NEWTON CD AND BURT JK. 1971. A review of 116 diaphragmatic hernias in dogs and cats. J Am Vet Med Assoc 159: 1142-1145.

WILSON TA, LEGRAND A, GEVENOIS PA AND DE TROYER A. 2001. Respiratory effects of the external and internal intercostals muscles in humans. J Physiol 530: 319-330.

WYNN J, ASPELUND G, ZYGMUNT A, STOLAR CJH AND MYCHALISKA G. 2013. Developmental outcomes of children with congenital diaphragmatic hernia: A multicenter prospective study. J Pediatr Surg 48: 1995 2004. 